\title{
FEATURE
}

\section{Societal value of soil carbon}

\author{
Rattan Lal
}

A griculture is an engine of economic development and is integral to any agenda for addressing global issues of the twenty-first century (e.g., food and nutritional security, climate change, growing energy and water demands, and biodiversity). By 2050, there will be an additional global food demand for cereal production by 1 billion $\mathrm{t}^{-1}(1.1$

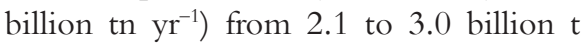
(2.3 to 3.3 billion $\mathrm{tn}$ ), and 200 million $\mathrm{t}$ $\mathrm{y}^{-1}\left(220\right.$ million $\left.\mathrm{tn} \mathrm{yr}^{-1}\right)$ of meat up to 470 million $\mathrm{t}^{-1}$ (518 million th $\left.\mathrm{yr}^{-1}\right)$ (FAO 2009; Alexandros and Bruinsma 2012). In addition, President Obama announced on June 2, 2014, that the US Environmental Protection Agency would cut carbon (C) emissions from the US power sector by up to $30 \%$ and soot and smog pollution by $25 \%$ by 2030 relative to 2005 levels (Kintisch 2014). There will also be an additional water demand of $40 \%$ by 2030 , in which soil-water storage (e.g., green water) will play a crucial role (Rosegrant et al. 2002). Indeed, major concerns of the modern civilization, especially peace and tranquility (Lal 2014), are intricately connected with soil and its quality, sustainable intensification of agriculture, and climateresilient farming through recarbonization of soil and the terrestrial biosphere.

Soil organic carbon (SOC; concentration and pool) and its dynamics are key determinants of soil quality and for the provisioning of essential ecosystem services (Koch et al. 2012; Stockman et al. 2013). Thus, soil should be appropriately defined as an organic C-mediated realm in which solid, liquid, gaseous, and biological components interact from nanometer to landscape scale to generate ecosystem services essential to all terrestrial life. The objective of this article is to describe the importance of SOC to addressing global issues, especially food security advancement and climate change mitigation and

Rattan Lal is a distinguished university professor of soil science and director of the Carbon Management and Sequestration Center, The Ohio State University, Columbus, Ohio.

\section{Table 1}

Comparison of environmental indicators in 1992 and 2014 (Brown 2010; Le Quere et al. 2013; Houghton 2003; WMO 2013; IPCC 1990, 2013; UN 2014; FAO 2011, 2014; IFDC 2010; World Bank 2014 ; WHO/UNICEF 2014).

\begin{tabular}{l} 
Parameters \\
\hline Total population $\left(10^{9}\right)$ \\
Urban population $\left(10^{9}\right)$ \\
Energy use $(\mathrm{EJ})$ \\
Fossil fuel emission (Pg C) \\
Emission from tropical deforestation (Pg C) \\
Water use $\left(\mathrm{km}^{3}\right)$ \\
Fertilizer use $\left(10^{6} \mathrm{Mg}\right)$ \\
Per capita arable land (ha) \\
Atmospheric carbon dioxide concentration (ppm) \\
Atmospheric methane concentration $(\mathrm{ppm})$ \\
Atmospheric nitrous oxide concentration $(\mathrm{ppm})$ \\
Per capita grain production ( $\mathrm{kg})$ \\
Poverty $\left(10^{9} ;<\right.$ US $\left.\$ 1.25 \mathrm{~d}^{-1}\right)$ \\
Ethanol production $\left(10^{9} \mathrm{~L}\right)$ \\
Hunger prone population $\left(10^{6}\right)$ \\
Lack of clean drinking water (people $\left.10^{9}\right)$ \\
Lack of access to sanitation (people $\left.10^{9}\right)$
\end{tabular}

adaptation. The inherent and societal value of SOC is also assessed.

\section{SOIL RESILIENCE VERSUS SUSTAINABLE DEVELOPMENT}

The Earth Summit, United Nations Conference on Environment and Development in Rio de Janeiro from June 3 to 14, 1992, proposed Agenda 21 on Sustainable Development (UN 1992). It is a nonbinding, voluntarily implemented action plan of the United Nations with regards to sustainable development. It is aimed at preparing the world for the challenges of the twenty-first century through sustainable environments and development. Section 4 specifically addresses the strategy of promoting terrestrial resource utilization and appropriate land use practices that contribute to (1) reduction of anthropogenic emissions of greenhouse gases (GHGs); (2) conservation, sustainable management, and enhancement of all sinks of GHGs; and (3) conservation and sustainable use of natural capital and environmental resources (e.g., soils). However, the analysis of data on global resources indicates that the strategy has not been as effective as was envisaged (table 1). For example, percentage increase of some environmentally sensitive parameters in 2014 compared with their value in 1992 is 32\% for total population, 39\% for urban population, $64 \%$ for energy use, $63 \%$ for fossil fuel emission of carbon dioxide $\left(\mathrm{CO}_{2}\right), 35 \%$ for fresh water use, and $52 \%$ for fertilizer consumption. An increase in atmospheric concentration of GHGs was also observed (by $13 \%$ for $\mathrm{CO}_{2}, 6.5 \%$ for methane $\left[\mathrm{CH}_{4}\right]$, and $5.5 \%$ for nitrous oxide $\left.\left[\mathrm{N}_{2} \mathrm{O}\right]\right)$. It is important to note, however, that absolute number of hunger-prone population decreased by $15.8 \%$, and the number of world poor $\left(<\mathrm{US} \$ 1.25 \mathrm{~d}^{-1}\right)$ decreased by $21 \%$. On the contrary, per capita land area decreased by $37 \%$, and grain consumption decreased by $4.2 \%$ (table 1 ).

The data in table 1 , and of numerous other critical parameters, clearly indicate that the goals of Agenda 21 have not been met, and neither have the targets of the so-called Millennium Development Goals (United Nations Development Programme 2000). Yet, the cost of adaptation to climate change can be high (Ahmed and Suphachalasai 2014). Thus, there is a strong need to critically and 


\section{Table 2}

Impacts of soil organic carbon concentration on soil quality. All qualities function together to provide resilience against climate change and other perturbations.

\begin{tabular}{ll}
\hline Soil & Soil parameter \\
\hline Physical quality & Aggregation and structural stability \\
& Tilth, resistance to crusting and compaction, and ease of cultivation \\
& Aeration and gaseous composition in soil air \\
& Water retention and availability \\
& Water transmission (infiltration and percolation) \\
& Heat capacity \\
& Surface area \\
& Soil strength/erodibility \\
& Cation exchange capacity \\
& Nutrient retention and availability \\
& Buffer capacity (against pH) \\
& Soil biodiversity \\
Chemical quality & Food and habitat for soil biota \\
& Net primary productivity \\
Biological quality & Use efficiency of input \\
& Nutrient cycling and biogeochemical transformations \\
& Carbon sequestration \\
& Rate of new soil formation \\
& Water purification \\
& Denaturing of pollutants \\
\end{tabular}

objectively reexamine the concept of sustainability (Benson and Craig 2014a). The resilience concept may be a better way to address environmental and natural resources challenges in an uncertain future (Showstack 2014) because the realities of anthropocene demands a new approach to environmental governance (Benson and Craig 2014b). The term "sustainable development" as perceived in Agenda 21 refers to a broader goal on strategy toward sustainable development with due consideration to the environment (concerns about climate change) and availability of natural resources (land, water, etc.). The data in table 1 show that neither the anthropogenic emissions have been reduced nor the concentrations of GHGs stabilized. The goals of eliminating hunger, poverty, and malnutrition remain as elusive as ever and merely a mirage.

Therefore, the focus is shifting toward "resilience" of social-ecological systems (SESs) and other innovative concepts because when indicators of climate change and the baseline of 1990 are in flux (moving targets), it is difficult to comprehend what is to be sustained.Agenda 21 assumed possession of both the knowledge about what can be sustained and the human capacity to achieve it. In contrast to main- taining stationarity, the resilience concept acknowledges disequilibrium and suggests techniques of assessing dynamic equilibrium among SESs and how to enhance the capacity to restore their functions (Benson and Craig 2014a, 2014b).

Soil, as a finite but essential resource, is prone to degradation, and risks of disequilibrium are exaggerated by climate change. Therefore, the strategy is to enhance soil's resilience against natural and anthropogenic perturbations (table 2). The key determinant of soil resilience is its SOC concentration, quality, and threshold level for meeting the ever-growing demands (food, feed, fiber, and fuel) of increasingly affluent humanity. Thus, the focus must be on judicious management of SOC concentration and pool.

\section{SOIL ORGANIC CARBON}

Soil organic matter (SOM) comprising of approximately $58 \%$ of SOC (which is a researchable issue in itself), is the basis of all physical, chemical, biological, and ecological transformations and reactions within a soil. Its importance has been recognized by farmers of all ancient civilizations. Asian farmers were able to cultivate the same field for as long as 40,000 years while maintaining soil fertility by managing SOM through manuring and recycling
(King 1911). Sir Albert Howard (1873 to 1947) stated that "the health of soil, plant, animal, and man is one and indivisible." Beginning in 1905, Sir Howard worked as an agricultural advisor in Indore, India, and realized the importance of SOM and recycling biomass to soil quality and productivity (Howard 1929, 1943). Howard strongly believed in the relationship between the rise and fall of civilizations and their agricultural practices and argued that "the real arsenal of democracy is a fertile soil, the fresh produce of which is the birthright of nations" (Howard 1945).

Recycling nutrients in the biomass (e.g., manure and compost) has been practiced for millennia in India, China, and other ancient civilizations. In ancient India, Kautilya (Chanakaya), a brahmin and a contemporary of Aristotle, was prime minister (326 to 301 BC) of the Emperor Chandragupta of the Mauryan Empire (326 to 200 BC). The book written in Sanskrit by Kautilya, Artha Sastra, has an important section on science of agricultural production and irrigation. Of the 15 books in Artha Sastra, chapter 14 in book 2 is entitled "Sitadhyaksha" or the "Superintendent of Agriculture" (Shamasastry 1915, 1961; Waldauer et al. 1996; Nene 2002; Tamboli and Nene 2010; Basu 2014). In the context of environment and ecology, Kautilya stated that sources of hazards pertaining to environment and ecology are human indiscretion and emphasized that a king should protect different types of forests and that water reservoirs (setu) be filled with water either from perennial sources or drawn from some other source (Shamasastry 1915). In Krishi-Parashara (a text on ancient Indian agriculture in Sanskrit), it is stated that crops grown without manure will not give yield. Kautilya mentioned the use of cow dung, animal bones, fish, milk, and manure to enhance soil fertility (Chaudhuri 1963). Ancient farmers in India believed that manuring is more important than plowing (Aiyar 1952). Green manure (plowing under of sesame) for crops, and liquid manure (kunapa) were recommended practices for trees (surapala) (Aiyar 1961). The importance of cow dung as a biofertilizer and a reservoir of soil fauna is still highly regarded (Srivastava et al. 2010).

Similar to India, China has a rich ancient literature on agricultural practices and soil 
management dating back to the dawn of farming. The Book of Odes explains agricultural practices dating back from Zhou dynasty (1027 to $771 \mathrm{BC}$ ) to 770 to 476 BC (Shi Jing) (Karlgren 1950). A compilation of 305 poems covering ancient life in China, it also describes landforms, animals, and plants. Houji, a legendary Chinese hero $(\sim 2100$ BC) in the middle reaches of Yellow and Yangtze rivers, is credited with introducing millet (Pennisetum glaucum) during the Xia dynasty. He developed the philosophy of agriculturalism in China and was famous for his luxurious crops of beans, rice, hemp, gourds, and millets (Wu 1982; Ho 1976).

In the book Kitab al-Filaha, written in the second half of the twelfth century, Ibn Al-'Awwam, a Moorish Arab from southern Spain described 585 plants and explained cultivation of more than 50 different fruit trees. He described soil quality with an important reference to SOM through soil color by stating that "the first step in the science of agriculture is the recognition of soils and of how to distinguish that which is of good quality and that which is of inferior quality... one must also consider the depth of the soilfor it often happens that its surface may be black" (Al-'Awwam 1866).

In the USDA Yearbook 3: Soils and Men, Albrecht (1938) stated that "SOM is one of our most important natural resources: its unwise exploitation has been devastating; and it must be given its proper place in any conservation policy as one of the major factors affecting the level of crop production soils, healthy people, and healthy animals" (Albrecht 1958). As president of Soil Science Society of America in 1938, he stated that "a declining soil fertility, due to a lack of organic material, major elements, and trace minerals, is responsible for poor crops and in turn for poor people." He also related health of teeth to the health of soils (Albrecht 1947) and argued that "health of our nation may be impossible to restore without first restoring the health of our soils."

\section{SOIL ORGANIC CARBON AND ECOSYSTEM FUNCTION}

There are several options of mitigating climate change by offsetting anthropogenic emissions and creating net negative balance in the future." He also believed in "healthy in the atmosphere (figure 1). Important among these are geo-engineering, reducing emissions, carbonation, and sequestering emissions by abiotic and biotic processes. Carbon sequestration in soil and vegetation is a promising option with numerous cobenefits. Further, SOC is a key parameter for maintaining soil physical, chemical, and biological quality (table 1). Thus, maintaining SOC concentration above the threshold level of $\sim 2 \%$ in the root zone is essential (Loveland and Webb 2003; Schjonning et al. 2010; Patrick et al. 2013). It is widely known that increase in SOC concentration in depleted soils increases crop yield (Lal 2006, 2010; Seremesic et al. 2011) and use efficiency of input, and has numerous global benefits (Govers et al.2012). The magnitude of yield increase depends on soil type, crop, management, antecedent SOC concentration, and the weather during the growing season. By enhancing soil resilience against extreme events and uncertain climate, and improving use efficiency of inputs, SOCinduced improvement in soil quality is critical to ensuring satisfactory crop yields even during a poor growing season. The literature is replete with data on favorable impacts of SOC on soil structure, erodibility, crusting, compaction, water retention, and transmission (Manlay et al. 2007; Feller et al. 2012; Six et al. 2002). In conjunction

\section{Figure 1}

Strategies of mitigating climate change. CSS = carbon capture and storage.

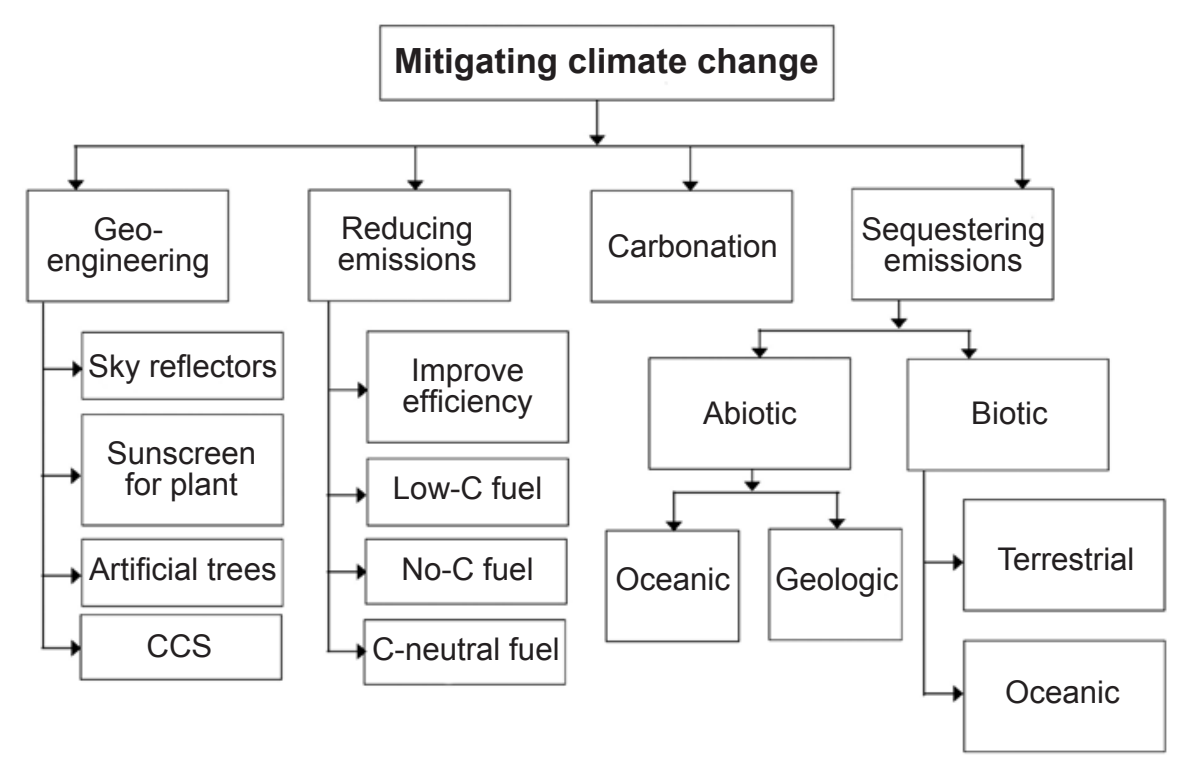
cally assessed (Johnson et al. 2010).

\section{NUTRIENTS REQUIRED TO CONVERT BIOMASS CARBON INTO SOIL ORGANIC CARBON}

with activity and species diversity of soil biota, improvement in SOC also creates disease-suppressive soils. Thus, the strategy of removing crop residues for biofuels and cellulosic ethanol production must be criti-

The process of biochemical transformation of biomass (crop residues, plants, and animal wastes) into SOC requires additional nutrients, especially nitrogen $(\mathrm{N})$, phosphorus (P), and sulfur (S) (figure 2). Most residues of cereals have a wide ratio of C:N (100), C:P (200), and C:S (500) compared with that of SOC at 12,50 , and 70 , respectively. Using these data and assuming the $\mathrm{C}$ concentration in cereal residues and the humification efficiency of $\sim 40 \%$, Himes (1997) estimated that sequestration of $10,000 \mathrm{~kg}(22,000 \mathrm{lb})$ of biomass $\mathrm{C}$ as SOC would require 62,000 $\mathrm{kg}(137,000 \mathrm{lb})$ of oven dry residue consisting of $28,000 \mathrm{~kg}(62,000 \mathrm{lb})$ of $\mathrm{C}$ and $833 \mathrm{~kg}(1,836 \mathrm{lb})$ of $\mathrm{N}, 200 \mathrm{~kg}(441 \mathrm{lb})$ of $\mathrm{P}$, and $143 \mathrm{~kg}(315 \mathrm{lb})$ of $\mathrm{S}$. This will produce $17,241 \mathrm{~kg}(38,010 \mathrm{lb})$ of humus. Without the availability of these essential nutrients, SOC concentration does not always increase even with long-term 


\section{Figure 2}

Nutrients required for biogeochemical transformation of biomass carbon (C) into soil organic carbon (SOC). The data on the amount of nitrogen $(\mathrm{N})$, phosphorus $(\mathrm{P})$, and sulfur (S) are from Himes (1997).

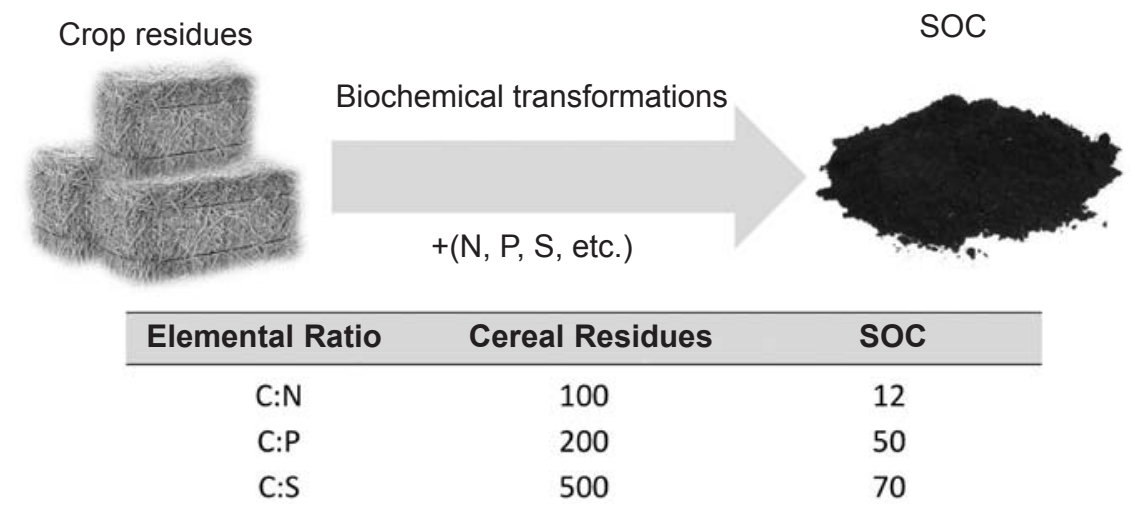

application of crop residues (Baker et al. 2007; Bissett et al. 2011). Similar calculations were made by Richardson et al. (2014) who estimated that increasing SOC by $1 \mathrm{Mg} \mathrm{C} \mathrm{ha}^{-1}\left(893 \mathrm{lb} \mathrm{C} \mathrm{ac}^{-1}\right)$ into humus requires 73,17 , and $11 \mathrm{~kg} \mathrm{ha}^{-1}(65$, 15 , and $10 \mathrm{lb} \mathrm{ac}^{-1}$ ) of $\mathrm{N}, \mathrm{P}$ and $\mathrm{S}$, respectively. Because nutrients are required both for crop production and $\mathrm{C}$ sequestration, Richardson and colleagues suggested the concept of "fertilizing the system" rather than the crop. Thus, there are significant and hidden costs of additional nutrients required for $\mathrm{C}$ sequestration.

\section{SOCIETAL AND INHERENT VALUE OF SOIL ORGANIC CARBON}

Reducing GHG emissions by $40 \%$ to $70 \%$ by 2050 necessitates removing $\mathrm{CO}_{2}$ from the atmosphere (or negative emissions) (Benson 2014). In addition to forestry measures (afforestation and reforestation), increasing $\mathrm{C}$ in soils has additional cobenefits. The societal value of soil $\mathrm{C}$ refers to the monetary equivalent of ecosystem services provisioned by a unit amount of SOC. The range of ecosystem services includes increasing net primary productivity and agronomic yield in the context of food and nutritional security, improving plant available water capacity in the root zone, reducing water runoff and soil erosion, minimizing sedimentation and nonpoint source pollution, offsetting anthropogenic emissions and mitigating/adapting to climate change, denaturing pollutants and purifying water, and enhancing biodi- versity. Assessing monetary value of these and other services is a major challenge (Costanza et al. 1997, 1998, 2014). It is indeed difficult to assess the real societal value of SOC. It has been a scientific challenge to assess the time it takes to create 1 $\mathrm{cm}(0.4 \mathrm{in})$ of surface soil. Soil is the most "priceless" gift of nature. It is not possible to assess its true worth in monetary terms.

In comparison, the inherent value of SOC can be estimated as the so-called "hidden cost" of all inputs, including crop residues/hay, fertilizers, and labor. Although a useful guide, the inherent cost of SOC must not be confused with its societal value. Just as the monetary value of an animal (human) cannot be computed by summing up the market values of nutrients in blood, bones, and tissues, so also the value of soil or SOC cannot be assessed by adding the monetary equivalent of its constituents (C, N, P, S, etc.). Indeed, life is more than the sum of its innate constituents. While treating SOC as a mixture of compounds, the monetary cost of these inputs must be adjusted for any benefits to farmers in terms of gain in productivity through water conservation and fertility improvement by nutrient cycling.

In continuation of the discussion regarding the inputs of crop residues and nutrients required to sequester $10,000 \mathrm{~kg}$ $(22,000 \mathrm{lb})$ of biomass $\mathrm{C}$ and transform it biochemically into $17,241 \mathrm{~kg}(38,010 \mathrm{lb})$ of humus, monetary costs of residues and fertilizer equivalent (tables 3 and 4) along with those of nutrients are estimated at
US $\$ 3,384$ (table 5). These costs must be adjusted for nutrients returned in the crop residues (table 3 and 4 or about US\$22.05 $\mathrm{Mg}^{-1}\left[\mathrm{US} \$ 20 \mathrm{tn}^{-1}\right]$ of residues with a total of US\$1,367), and the agronomic benefits in crop yields (5\% increase due to soil moisture conservation for 6 ha $[14.82 \mathrm{ac}]$ for a total gain of $3 \mathrm{Mg}$ [138 bu] of grains with an average price of US $\$ 5 \mathrm{bu}^{-1}$ for a total gain of US\$690) through soil and water conservation and improvements in soil quality, leaving a net cost of (US $\$ 3,384$ - US\$2,057 = US\$1,327) for 10,000 $\mathrm{kg} \mathrm{C}(22,000 \mathrm{lb} \mathrm{C})$ at US\$132.70 $\mathrm{Mg}^{-1}$ $\left(\mathrm{US} \$ 120.40 \mathrm{tn}^{-1}\right.$ ) C or US\$36.20 $\mathrm{Mg}^{-1}$ (US\$32.80 $\mathrm{tn}^{-1}$ ) $\mathrm{CO}_{2}$. Thus, the inherent value of SOC is US\$0.13 $\mathrm{kg}^{-1}$ (US\$0.05 $\mathrm{lb}^{-1}$ ) C, US\$0.075 $\mathrm{kg}^{-1}$ (US\$0.034 $\mathrm{lb}^{-1}$ ) of SOM (58\% C), and US\$0.035 kg-1 $(\$ 0.016$ $\mathrm{lb}^{-1}$ ) of $\mathrm{CO}_{2}$. If only the cost of nutrients $(\mathrm{N}$, $\mathrm{P}$, and $\mathrm{S}$ ) is considered, the cost of SOC is US\$1,028 for $10,000 \mathrm{~kg} \mathrm{C}(22,000 \mathrm{lb} \mathrm{C})$, US $\$ 0.10 \mathrm{~kg}^{-1}$ (US\$0.045 $\mathrm{lb}^{-1}$ ) of $\mathrm{C}$, and US $\$ 0.03 \mathrm{~kg}^{-1}\left(\$ 0.013 \mathrm{lb}^{-1}\right)$ of $\mathrm{CO}_{2}$.

These costs are estimates and vary from country to country and year to year depending on the price of fertilizers, grains, stover, and other market forces. The objective of this exercise is not to provide a precise value but to demonstrate the concepts so that inherent or the societal value can be computed on the basis of the hidden costs of the inputs involved.

PAYMENTS FOR ECOSYSTEM SERVICES

Carbon farming is rapidly becoming the new agriculture where $\mathrm{C}$ sequestered in soil/trees/wetlands could be traded just as any other farm produce. Alternatively, farmers would be compensated for provisioning of ecosystem services through $\mathrm{C}$ sequestration in soil/biomass (Lal et al. 2013). Three mechanisms of compen-

\section{Table 3}

Estimation of nutrients contained in crop residues (USDA 2008).

\begin{tabular}{llll}
\hline & \multicolumn{3}{l}{ Nutrient concentration (\%) } \\
\cline { 2 - 4 } Crop & Nitrogen & Phosphorus & Potassium \\
\hline Corn & 0.97 & 0.10 & 1.52 \\
Wheat & 0.61 & 0.06 & 1.17 \\
Sorghum & 0.77 & 0.115 & 1.01 \\
Rice & 0.70 & 0.09 & 1.48
\end{tabular}




\section{Table 4}

Price of fertilizer nutrients (AfricaFertilizer.org 2014).

\begin{tabular}{|c|c|c|c|}
\hline Nutrient & Form & Cost (US\$ $\mathrm{Mg}^{-1}$ ) & Nutrient cost $\left(\mathrm{US} \$ \mathbf{~ k g}^{-1}\right)^{*}$ \\
\hline \multirow[t]{3}{*}{ Nitrogen } & Urea & 300 to 500 & 0.67 to $1.0(0.84)$ \\
\hline & Anhydrous ammonia & 400 to 500 & 0.49 to $0.61(0.55)$ \\
\hline & Ammonium sulfate & 120 to 150 & 0.57 to $0.71(0.64)$ \\
\hline \multirow[t]{3}{*}{ Phosphorous } & Mono-ammonium phosphate & 400 to 500 & 1.67 to $2.08(1.88)$ \\
\hline & Di-ammonium phosphate & 380 to 500 & 1.90 to $2.50(2.22)$ \\
\hline & Tri-ammonium phosphate & 300 to 390 & 1.50 to 1.95 (1.73) \\
\hline Potash & Muriate of potash & 300 to 400 & 0.57 to $0.76(0.67)$ \\
\hline Compound & NPK (16:16:16) & 320 to 400 & 0.67 to $0.83(0.75)$ \\
\hline Sulfur & $\mathrm{s}$ & 500 to 630 & 0.50 to $0.63(0.57)$ \\
\hline
\end{tabular}

*Numbers in parentheses are average price per kilogram of nutrient.

\section{Table 5}

Monetary cost of converting biomass into soil organic matter/soil organic carbon (C).

\begin{tabular}{|c|c|c|c|}
\hline Ingredients & Amount (kg) & Price (US\$ kg-1) & Total price (US\$) \\
\hline Residues & $62,000 *$ & 0.038 & 2,350 \\
\hline Nitrogen & 833 & 0.67 & 558 \\
\hline Phosphorus & 200 & 1.94 & 388 \\
\hline \multirow[t]{2}{*}{ Sulfur } & 143 & 0.57 & 82 \\
\hline & & Total & 3,384 \\
\hline
\end{tabular}

sating farmers are (1) C credits based on cap and trade, (2) C maintenance fees, and (3) payments for ecosystem services. All of these three mechanisms must consider the inherent value of soil C.

It is the understanding of basic principles governing the value of scientific concepts which leads to innovation and judicious management of natural resources. The human wellbeing depends on appropriate use of science. Humanity is once again grappling with a myriad of strong challenges (e.g., climate change, soil degradation, water scarcity, and food and nutritional security). Successfully addressing these challenges necessitates assigning societal value to critical resources (e.g., SOC). Undervaluing SOC, or other resources such as water, can lead to tragedy of the commons. Not only can the innovations be hindered by undervaluing a resource, but it is prone to exploitation by greed and for making quick returns by cutting corners for short-term gains. Therefore, assigning appropriate societal value to SOC and implementing policies for its judicious management are critical to ecological restoration of our once and future planet (Woodworth 2013) so that soils will always save us (Ohlson 2014).

\section{THE SOIL ICON}

Soil is the basis and essence of all terrestrial life. The Gaia hypothesis states that all organisms and their inorganic surroundings on Earth are closely integrated to form a single and self-regulating complete system, maintaining the conditions of life on the planet (Lovelock 1979). Earthbased spirituality and earth wisdom (Kjos 1992) is gaining momentum. Thus, natural resource conservation is increasingly being linked with stewardship and spirituality (Wallace and Clearfield 1997). An icon, with a universal appeal, is needed to enhance awareness about the importance of soil in all daily life. Just as a panda has been used as a symbol of wildlife, a polar bear on an ice patch of global warming, so is an urgent and strong need for a soil icon as a symbol of all terrestrial life and numerous ecosystem functions and services. Such an icon can be a useful education tool for second to twelfth grade students, a promo- tional poster for media, and an advocacy protocol for policy makers. An example of such an icon, which can be and should be improved, is shown in figure 3 and indicates that all life (microbes, plants, animals, and humans) depend on a healthy soil.

\section{CONCLUSIONS}

As efforts are made to assign value to and manage our soil resources, the following should kept in mind:

- Restoring SOC concentration to above the critical level $(\sim 2.0 \%)$ in the root zone is essential to ecosystem functions, provisioning of critical services, (e.g., food and nutritional security, resilience to climate change, water quality, biodiversity).

- There are hidden costs of SOC restoration through biochemical transformations of biomass $\mathrm{C}$ into residues. These costs include those of crop residues/biomass and nutrients (e.g., N, P, $\mathrm{S})$. The monetary equivalent of inherent cost or societal value of SOC is $\sim \mathrm{US} \$ 0.133 \mathrm{~kg}^{-1}$ (US $\left.\$ 0.060 \mathrm{lb}^{-1}\right)$.

- With an average sequestration rate of $300 \mathrm{~kg} \mathrm{C} \mathrm{ha}^{-1} \mathrm{y}^{-1}\left(267 \mathrm{lb} \mathrm{C} \mathrm{ac}^{-1} \mathrm{yr}^{-1}\right)$ through adoption of best management practices, farmers should be compensated for provisioning of ecosystem services (climate change mitigation, water quality, biodiversity, etc.) at the rate of US $\$ 40 \mathrm{ha}^{-1} \mathrm{y}^{-1}\left(\mathrm{US} \$ 16 \mathrm{ac}^{-1} \mathrm{yr}^{-1}\right)$.

- Humus/SOC is a finite but essential natural capital, and it must be used, enhanced, and restored by land use and management systems that create a positive soil/ecosystem C budget, by decreasing losses (e.g., erosion and decomposition) and increasing input (e.g., crop residues, cover cropping, and manuring) and recommended management practices (e.g., conservation agriculture).

\section{REFERENCES}

AfricaFertilizer.org. 2014. Monthly International Prices for Fertilizers. www.argusmedia.com/fertilizer; AfricaFertilizer.org.

Ahmed, M., and S. Suphachalasai. 2014. Assessing the Costs of Climate Change and Adaptation in South Asia. Mandaluyong City, Phillipines: ADB Asian Development Bank.

Aiyar, V.V.S.T. 1961. The Kural, or the Maxims of Tiruvalluvar. Trichinapulli, India: Teynampet. 


\section{Figure 3}

Soil is the essence of all terrestrial life. A possible "soil icon" indicating the life-support services of soil.

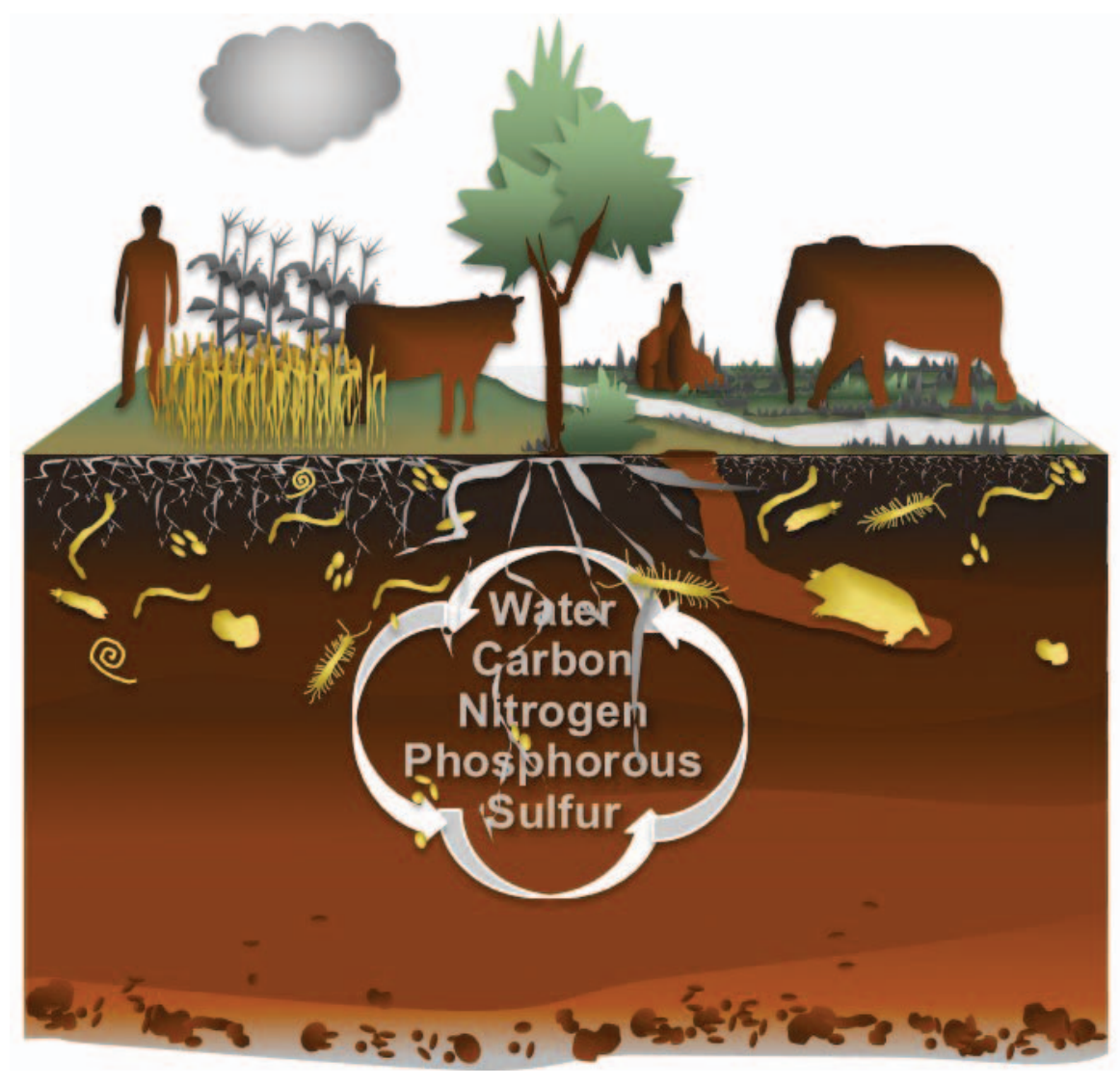

Al-'Awwam, I. 1866. Kitab al-Filaha, Le Livre de l'Agriculture, translated from Aabic by J.-J. Clement-Mullet. Paris, France: Librairie A. Franck.

Albrecht, W. 1938. Soils and Men: Yearbook of Agriculture. Washington, DC: USDA.

Albrecht, W. 1958. Impoverished Soils, Poor Animal

Health, and Distorted Economies for Agriculture. Soil Fertility and Animal Health. Webster City, Iowa: The Fred Hahne Printing Company.

Albrecht,W.A. 1947. Our Teeth and Our Soils, Annals of Dentistry 6.

Alexandros, N., and J. Bruinsma. 2012. World Agriculture towards 2030/2050. Rome, Italy: Food and Agriculture Organization of the United Nations.

Baker, J.M., T.E. Ochsner, R.T. Venterea, and T.J. Griffis 2007. Tillage and soil carbon sequestration-What do we really know? Agricultural Ecosystems Environments 118:1-5.

Basu, R.L. 2011. Kautilya's Arthasastra 300 B.C.: Economic Ideas. Kolkata India: Self-published.

Benson, M.H., and R.K. Craig. 2014a. The end of sustainability: The realities of Anthropocene vices: Putting the issues in perspective. Ecological Economics 251:67-72.

Costanza, R., R. d'Arge, R. deGroot, S. Farber, M. Grasso, B. Hannon, K. Limburg, S. Naeem, R. O'Neill, J. Paruelo, R. Raskin, P. Sutton, and M. van den Belt. 1997. The value of the world's ecosystem services and natural capital. Nature 3876630:253-260.

Costanza, R., R. de Groot, P. Sutton, S. van der Ploeg, S. Anderson, I. Kubiszewski, S. Farber, and R. Turner. 2014. Changes in the global value of ecosystem services. Global Environmental Change-Human and Policy Dimensions 26:152-158.

FAO (Food and Agriculture Organization of the United Nations). 2009. How to feed the world in 2050? Rome, Italy: Food and Agriculture Organization of the United Nations.

FAO. 2011. Current world fertilizer trends and outlook to 2015. Rome, Italy: Food and Agriculture Organization of the United Nations.

FAO (Food and Agriculture Organization of the United Nations). 2014. FAO Stat. Rome, Italy: Food and Agriculture Organization of the United Nations.

Feller, C., E. Blanchart, M. Bernoux, R. Lal, and R. Manlay. 2012. Soil fertility concepts over the past two centuries: The importance attributed to soil organic matter in developed and developing countries. Archives of Agronomy and Soil Science 58:S3-S21.

Govers, G., R. Merckx, K. Van Oost, and B. van Wesemae. 2012. Soil organic carbon management for global benefits: A discussion paper. Soil Organic Carbon Benefits: A Scoping Study. Nairobi, Kenya: G.G.E.F. Scientific and Technical Advisory Panel.

Himes, F.L. 1997. Nitrogen, sulfur, and phosphorus and the sequestering of carbon. In Soil Processes and the Carbon Cycle, ed. R. Lal, J.M. Kimble, R.F. Follett, and B.A. Stewart. Boca Raton, FL: CRC Press.

Ho, P.T. 1976. Cradle of the East: An Enquiry into the Indigenous Origins of Techniques and Ideas of Neolithic and Early Historic China, 5000-1000 B.C. Hong Kong: Chinese University of Hong Kong.

Houghton, R. 2003. Revised estimates of the annual net flux of carbon to the atmosphere from changes in land use and land management 18502000. Tellus Series B-Chemical and Physical Meteorology 552:378-390.

Howard, A. 1929. The Development of Indian Agriculture. Bombay, India: H. Milford, Oxford University Press.

Howard, A. 1943. An Agricultural Testament. New York: Oxford University Press. 
Howard, A. 1945. The Soil and Health: A Study of Organic Agriculture. Lexington, KY: The University Press of Kentucky.

IFDC (International Fertilizer Development Center). 2010. Global and Regional Data on Fertilizer Production and Consumption. Muscle Schoals, AL: International Fertilizer Development Center. IPCC (Intergovernmental Panel on Climate Change). 1990. Climate Change: The IPCC Scientific Assessment 1990. Cambridge, UK: Cambridge University Press.

IPCC. 2013. Climate Change 2013: The Physical Science Basis, The Fifth Assessment Report. Cambridge, UK: Cambridge University Press.

Johnson, J., W. Wilhelm, D. Karlen, D. Archer, B. Wienhold, D. Lightle, D. Laird, J. Baker, T. Ochsner, J. Novak, A. Halvorson, F. Arriaga, and N. Barbour. 2010. Nutrient removal as a function of corn stover cutting height and cob harvest. Bioenergy Research 34:342-352.

Karlen, D. 2008. Presentation Alabama Energy Summit. Sept. 17, 2008.

Karlgren, B. 1950. The Book of Odes: Chinese Text, Transcription and Translation. Stockholm: The Museum of Far Eastern Antiquitites.

King, F.H. 1911. Farmers of Forty Centuries: Or Permanent Agriculture in China, Korea and Japan. New York: Courier Dover Publications.

Kintisch, E. 2014. Climate Change: A bold baby step on emissions. Science 3446188:1070-1071.

Kjos, B. 1992. Under the spell of Mother earth. Bel Air, CA:Victor Books.

Koch, A., A. McBratney, and R. Lal. 2012. Global soil week: Put soil security on the global agenda. Nature 492:186.

Lal, R. 2006. Enhancing crop yields in the developing countries through restoration of the soil organic carbon pool in agricultural lands. Land Degradation and Development 172:197-209.

Lal, R. 2010. Enhancing eco-efficiency in agro-ecosystems through soil carbon sequestration. Crop Science 502:S120-S131.

Lal, R. 2014. Soil-peace nexus: Our common future. Soil Science and Plant Nutrition. In Press.

Lal, R., K. Lorenz, R.R.J. Hüttl, B.U. Schneider, and J. von Braun. 2013. Ecosystem Services and Carbon Sequestration in the Biosphere. Dordrecht, Netherlands: Springer.

Le Quere, C., G.P. Peters, R.J. Andres, R.M. Andrew, and T.A. Boden. 2013. Global carbon budget 2013. Earth System Science Data 6:235-263.

Loveland, P., and J. Webb. 2003. Is there a critical level of organic matter in the agricultural soils of temperate regions: A review. Soil and Tillage Research 701:1-18.
Lovelock, J. 1979. Gaia: A new look at life on Earth. Oxford, UK: Oxford University Press.

Manlay, R., C. Feller, and M. Swift. 2007. Historical evolution of soil organic matter concepts and their relationships with the fertility and sustainability of cropping systems. Agriculture, Ecosystems and Environment 1193-4:217-233.

Nene, Y.L. 2002. Modern agronomic concepts and practices evident in Kautilya's Arthasastra c. 300 BC. Asian Agri-History 63:231-242.

Ohlson, K. 2014. The Soil Will Save Us: How Scientists, Farmers, and Foodies Are Healing the Soil to Save the Planet. New York: Rodale Books.

Patrick, M., J.S. Tenywa, P. Ebanyat, M.M. Tenywa, D.N. Mubiru, T.A. Basamba, and A. Leip. 2013. Soil organic carbon thresholds and nitrogen management in tropical agroecosystems: Concepts and prospects. Journal of Sustainable Development 612:31-43.

Richardson, A.E., C.A. Kirby, S. Banerjee, and J.A. Kirkegaard. 2014. The inorganic nutrient cost of building soil carbon. Carbon Management. In Press.

Rosegrant, M.W., X. Cai, and S.A. Cline. 2002. Global Water Outlook to 2025: Averting an Impending Crisis. Washington, DC, and Colombo, Sri Lanka: International Food Policy Research Institute and International Water Management Institute.

Schjonning, P., L.W. de Jonge, P. Moldrup, B.T. Christensen, and J.E. Olesen. 2010. Searching the critical soil organic carbon threshold for satisfactory tilth conditions - test of the Dexter clay: carbon hypothesis. Proceedings of the First International Conference and Exploratory Workshop on Soil Architecture and Physicochemical Functions. Cesar. L. W. de Jonge, P. Moldrup, and A.L. Vendelboe. Tjele, Denmark: Aarhus University, Faculty of Agricultural Sciences, Research Centre Foulum.

Seremesic, S., D. Milosev, I. Djalovic, T. Zeremski, and J. Ninkov. 2011. Management of soil organic carbon in maintaining soil productivity and yield stability of winter wheat. Plant Soil and Environment 575:216-221.

Shamasastry, R. 1915. Kautilya:Arthashastra. Banglore, India: Government Press.

Shamasastry, R. 1961. Kautilya's Arthasastra. Mysore, India: Mysore Printing and Publishing House.

Showstack, R. 2014. Sustainability as environmental framework may be outdated. Eos 95:262-263.

Six, J., C. Feller, K. Denef, S. Ogle, J. Sa, and A. Albrecht. 2002. Soil organic matter, biota and aggregation in temperate and tropical soils Effects of no-tillage. Agronomie 227-8:755-775.

Srivastava, R., M. Aragno, and A. Sharma. 2010. Cow dung extract: A medium for the growth of pseudomonads enhancing their efficiency as biofertilizer and biocontrol agent in rice. Indian Journal of Microbiology 503:349-354.

Stockmann,U., M.A. Adams, J.W. Crawford, D.J. Field, N. Henakaarchchi, M. Jenkins, B. Minasny, A.B. McBratney, V.de R.de Courcelles, K. Singh, I. Wheeler, L. Abbott, D.A. Angers, J. Baldock, M. Bird, P.C. Brookes, C. Chenu, J.D. Jastrow, R. Lal, J. Lehmann, A.G. O’Donnell, W.J. Parton, D. Whitehead, and M.J. Zimmerman. 2013. The knowns, known unknowns, and unknowns of sequestration of soil organic carbon. Agriculture, Ecosystems and Environment 164:80-99.

Tamboli, P., and Y. Nene. 2002. Science in India with Special Reference to Agriculture. Secunderabad, India: Asian History Foundation.

UN (United Nations). 1992. United Nations Conference on Environment and Development UNCED.The Earth Summit, Rio de Janeiro, Brazil.

UN. 2014. World Water Development Report 2014Water and Energy. New York: United Nations.

United Nations Development Programme. 2000. The United Nations Millennium Development Goals (Eight Goals for 2015), signed by 191 UN member states in September 2000. New York: United Nations.

UNICEF/WHO (United Nations Children's Fund). 2014. Joint Press Release. The Need to Reduce Gaps in Access to Improved Drinking Water and Sanitation. Paris, France: UNICEF Press Center.

USDA NRCS (Natural Resources Conservation Service). 2008. Harvesting crop residues: What is it worth? Iowa Fact Sheet. Des Moines, IA: Natural Resources Conservation Service.

Waldauer, C., W. Zakha, and S. Pal. 1996. Kautilya's Arthashastra: A neglected precursor to classical economics. Indian Economic Review XXXI1:101-108.

Wallace, B., and F. Clearfield. 1997. Stewardship, spirituality and natural resources conservation, a short history. Technical Report Release 2.2. Washington, DC: Social Sciences Institute, USDA.

Woodworth, P. 2013. Our Once and Future Planet: Restoring the World in the Climate Change Century. Chicago, IL: University of Chicago Press. World Bank. 2014. Poverty and Equity Data. http:// povertydata.worldbank.org/poverty/home/.

WMO (World Meteorological Organization). 2013. Greenhouse Gas Bulleting \#9. Geneva, Switzerland:World Meteorological Organization. Wu, K.C. 1982. The Chinese Heritage. New York: Crown Publisher. 